Volume 10, No.5, September - October 2021

International Journal of Advanced Trends in Computer Science and Engineering

Available Online at http://www.warse.org/IJATCSE/static/pdf/file/ijatcse061052021.pdf

https://doi.org/10.30534/ijatcse/2021/061052021

\title{
Applying Growth Hacking Method to Identify Customer Profile with Big Data Framework in Telecommunication Company
}

\author{
Raden S.B.Cokro ${ }^{1}$, Edie Kurniawan ${ }^{2}$,Timothy Gondomulio ${ }^{3}$, Gunawan Wang ${ }^{4}$, Emil Kaburuan ${ }^{5}$, Gomgom $^{6}$ \\ ${ }^{1}$ PT PLN (Persero) Pusdiklat UPDL Jakarta, Indonesia, 11440. \\ ${ }^{2,3,4,5,6}$ Information Systems Management Department, BINUS Graduate Program - Master of Information Systems \\ Management, Bina Nusantara University, Indonesia, 11480. \\ e-mail: ${ }^{1}$ radencokro@pln.co.id, ${ }^{2}$ edie.kurniawan@binus.ac.id, \\ 3timothy.gondomulio@binus.ac.id, ${ }^{3}$ gwang@binus.edu, ${ }^{5}$ emil.kaburuan@binus.edu, ${ }^{6}$ gomgom@binus.ac.id
}

Received Date : August 03, 2021 Accepted Date : September 16, $2021 \quad$ Published Date : October 06, 2021

\begin{abstract}
We can't deny that there are two things that take the biggest cost in marketing: The first one is the cost for advertising in TVc, newspapers, radios, and the second one is the sales fee for door-to-door marketing. Enterprise is pushed to increase the amount of sales and revenue as high as it can, and decrease the marketing cost especially for advertising and sales fee. Growth Hacking could be an alternative media to raise 4 elements often called AIDA (Awareness, Interest, and Action) of a product for market target that can be classified based on customer's desire, needs, and behaviors. This classification can be gained by big data analysis. This paper will discuss about the use of growth hacking which at first used by many startups, new enterprise with services and products rarely known. We try to implement growth hacking in a market-leader company with well-known products, but the investment and competition level are still high. How to apply it and get the insight from the implementation. This paper also discusses the role of big data in mapping customer behavior in specific locations so that the content of Growth Hacking can be received by prospective customers without rejection of campaign in growth hacking.
\end{abstract}

Key words: Growth Hacking, Big data, Customer Behaviour

\section{INTRODUCTION}

These days, a company has to choose a way to promote a product or service, it can be with conventional media or digital media. Global Web Index has surveyed 391,130 respondents in 41 countries. Digital customer now has spent 6 hours 45 minutes online, and 3 hours 18 minutes spent on their smartphone. While the time spent on television, whether its streaming, cable, or free, is almost stable, from 4 hours 54 minutes to 4 hours 59 minutes in the same period

In Figure 1, If the number of Indonesia's population in 2018 is 264.16 million, it results the internet user in Indonesia which reach 171.17 millions of people. This number is gained from all of the Indonesian people in various province.
The distribution of internet users in Indonesia as follows: $55 \%$ in Java Island, $21 \%$ in Sumatera Island, $10 \%$ in Sulawesi Island, $10 \%$ in Maluku Island, $10 \%$ in Papua Island, 9\% in Kalimantan Island, 5\% in Bali Island, and 5\% in Nusa Tenggara Island.

Java island got the most internet users. We can break down Java Island into some regions as follows: $16.6 \%$ internet users in West Java, 14.3\% in Central Java, 13.5\% in East Java, $4.7 \%$ in Jakarta, and $1.5 \%$ in Yogyakarta.

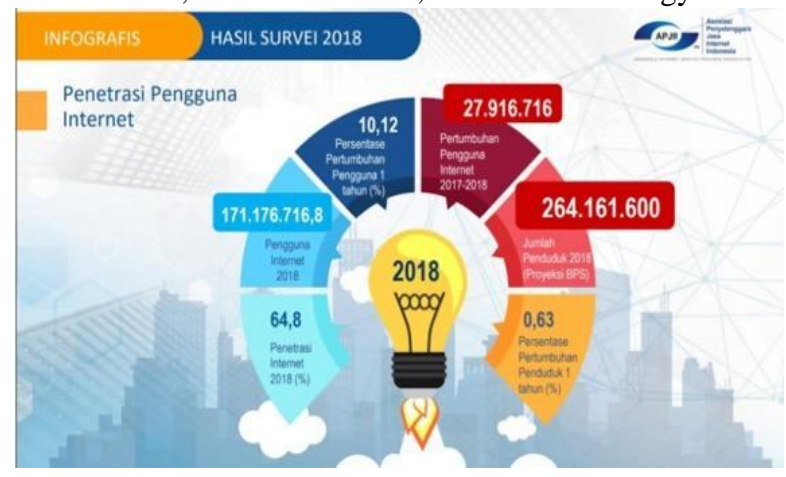

Figure 1: Result of a survey by APJI (Asosiasi Penyelenggara Jasa Internet Indonesia) 2019

To gain awareness about broadband products and services from internet users and to make them do an action to buy by door-to-door, it may takes so many people and high cost. Another choice is to put an advertising on TVc and based on CEO Adstensity A. Sapto Anggoro, the cost for it is 110.46 trillion rupiah.

With the digital development explained above, the elements of marketing are also changing. Product, Place, Promotion, Sales, and Promotion Channel are shifted from physical channel to omnichannel with the rise of digital channels such as Web and Social Media (Facebook, Twitter, Instagram, Whatsapp, Telegram chat).

Growth Hacking appears as an alternative solution in introducing product and service with relatively lower cost and could massively reach bigger target in the market. At first it was used by startup companies which are new and wants to accelerate the distribution of their product and service awareness with efficient cost. 
Growth Hacking itself is a method to get a business viral with low budget, high impact. Willix Halim, Vice President of Growth \& Data Science from Freelancer.com said that growth hacking is a deep analysis mechanism towards data so companies can understand their users, and how users adopt their product, and also what feature that they could deliver.

In fact, the concept of growth hacking has already been used long time ago by some American digital companies. Basically this method prioritize CUSTOMERS, what they need? Where are they? And how the behave? All of this could be known by bringing website and social media analytics, this is where the role of Big Data plays.

As an insight with data from a broadband company called PT. Telkom, the composition of sales contribution from distribution channel in 2018 are: $90 \%$ sales from Push Channel, in this case it's Sales Force who did the door-to-door sales and open table in residential location, and the other $10 \%$ comes from the Inbound Call towards the Call Center, Web, and Apps. With the high dependency to Salesforce, it makes the sales cost grows very high with the spread range of product AIDA is very limited, so it will be hard to spread information quickly to 36,097 village from Sabang to Merauke in Indonesia if we count on physical sales by door-to-door method.

According to Sean Ellis, the creator of Growth Hacking, Growth Hacking is the application of scientific method for the design, implementation, and testing of repeatable and scalable strategies to maximize the metrics at each stage of the overall product of the digital product. It's a methodology that consists of experimenting, analysing, devising, and prioritizing different determined objectives. It means making quick decisions and doing experiments that cost little. This technique combines creative marketing, analytic, and software engineering to spread digital ads in accordance with customer's trends, preferences, desires, and needs.

Looking at the lifestyle change of the people in using social media and other digital services, in this paper we want to discuss does Growth Hacking could bring success quickly: Airbnb could gain total income around 2.6 billion or equal with 36 billion rupiah in 2017, Quora uses growth engineering technique. This technique makes them one of the most leading Q\&A forum in the world, Dropbox adds up their new users up to 4 million users in only 15 months and now it reaches 500 million users with the size of content collected up to 400 billion content, or Bukalapak who can invite up to 500 thousands of small business owners to sell their products in Bukalapak with quadrupled transactions from the previous year, where its GMV reaches 4 trillion per month.

Taking into account the above explanation, we can know why companies today use growth hacking. Continue briefly about the reasons as follows:

1. Very limited company resource, so must find a faster and more efficient way to get and win the target market
2. The channels of promotion and sales through traditional channels are very expensive and very common, too many company used it

3. Challenge the future for the success of a company is no longer just a product but how the distribution channel and how to buy market penetration through the distribution channel created

The important thing that really supports the implementation of growth hacking is Big Data. With Big Data, the content that will be brought and spread through growth hacking will be in accordance with the needs and requirements of customers.

[16] Big data can be seen from the very large volume of data that contains related matters, which are needed by structured and unstructured companies every day. This important data is big data, with changes that are fast enough, and complex which may not be in accordance with the manual or traditional way.

Dough Laneh an industry analyst in early 2000 introduced Big Data with $3 \mathrm{~V}$ : Volume, Velocity and Variety

Volume is data from various sources both internal and external, data about transactions, about customer complaints, about recurring payments, about when customers buy, about demographic and geographic profiles and much more

Velocity in this case is data retrieval and data handling quickly to the data needed in the previous paragraph at the same time

Varietty can be explains as variations from data both structured and unstructured data, numerical data, transaction data, demographic data, geography, email, social media, words that are often searched on search engines and more

At www.sas.com there is an addition of $2 \mathrm{~V}$ when explaining Big Data namely Variability and Veracity

Variability speaks of data related to events, for example trends in social media, in the news, or in over the top services such as WhatsApp, Telegram and others.

Veracity is related to the truth and value of data, or simply related to data quality. Data sources determine the validity and quality of the data. The data obtained must be selected, sorted, linked according to company needs.

Big Data does not focus on the amount of data or the number of data sources. Big Data will be useful to obtain the required data from a valid source. So when we use big data, the goal is to minimize time in gaining insightful data that is important for company development, can reduce costs compared to having to conduct surveys in the field, and be able to choose and determine the right decision.

When selecting data, correlating, displaying data from big data, we can immediately know various kinds of information, for example about locations where the highest and lowest sales and causes, locations of payment 
methods preferred by customers, do traking if there are irregularities in the delivery of goods or cheating.

Keeping in mind the growth of hacking, and the role of big data in determining customer behavior, this paper is discussed to illustrate the step-by-step implementation of growth hacking in helping sales penetration in accordance with customer behavior and needs obtained from big data

\section{LITERATURE REVIEW}

\subsection{Growth Hacking Literature}

In $[4,8]$, it is explained that Growth hacker marketing changes the approach of regards to marketing products or services. Usually we know product driven, where customers are forced to accept marketing content and our products, but with growth hacker marketing, promotion, dissemination of information related to products and services tailored to customer needs and customer behavior. Customers indirectly through big data can be involved in planning and developing desired products and what information is desired. Growth hacker marketing analytically uses big data to study customer profiles, customer behavior, how much budget and time is available for customers to consume services in a more efficient, measurable and scientific way (Holiday, 2013)

The challenge is how to be cost efficient, so start up companies and existing companies can achieve high business growth in a short time.. As explained by Bussgang and Benbarak (2016, paragraph 15, "if data is the fuel of growth, analytics are the engine." With the right data, and the implementation of growt hacking, it is expected that user growth will be high, income will increase and profits will be high.

In [7], Sean Ellis in 2010 created and defined Growth Hacking. The main purpose of growth hacking is to grow the company's business fast by out of the box and ignoring traditional marketing patterns

In [10] The idea of growth hacking encompasses two goals. The first one is to obtain a maximum number of customers at the lowest possible cost by using mechanisms of viral distribution of content in social media. Secondly, the strategy aims to retain customers by shaping their positive experiences through continuous development and product improvement.

Advantages is what growth hacking is about. It is cheaper than conducting marketing communication activities on a broad scale and helps a product to reach a large group of potential customers at the same time. Without costly research, it also allows such product optimization to satisfy and ultimately retain current customers. As numerous examples of organizations show, following the approach brings measurable results.

In [10-11] his interview, given to M. Pudełek and S. Pieczyński, A. Morawski says: "A growth hacker is somebody who tests, checks, analyzes and experiments. All of these is done to find a Product Market Fit (PMF) a product tailored to recipients" needs. After that they develop a strategy and optimization process. To do this, growth hackers observe and predict consumer behavior. The conducted research allows them to develop a suitable strategy and process which target a possibly widest group of recipients and persuade them with their offer. At the same time, they do not abandon traditional types of advertising and communication. Quite contrary, they use them all at the same time. Nonetheless, their main aim is to form a situation in which our advertisement or activity will be continued by users themselves (Pudełek \& Pieczyński, 2017).

In [13], there are (three) activities in Consumer Marketers: (1) Seek consumer insights and build creative marketing, (2) Data Scientists: Formulate hypotheses and design tests to improve KPIs, (3)Software Engineers: $\square$ Build tools to automate these tests

\subsection{Big Data Literature}

The relationship between growth hacking with big data is very close. For successful implementation of growth hacking, big data must be able to answer the reason customers buy existing services and products. In the customer journey it will be very difficult if we look for answers using manual analysis of existing data. Stages of the customer's journey to buying products and services pass through many possible aspects that influence purchasing decisions from the purchase goal, price consideration, distribution channel consideration, consideration of competitors' offers, and many others. So often the customer's mind is compared to a black box where no one can know the reason for making a purchase

In [14] (Tekiner, F., \& Keane, J. A) explained the characteristics of Big Data. These characteristics are explained in detail as follows:

1. Data Quantity in the form of volume, width or scale of data and its processing

2. Diversity and uniqueness of data makes the data very varied, this is caused by various types of data itself and various types of data sources

3. Speed and accuracy, with so many events, noise on social media, various kinds of news that are released on the internet, it needs speed and accuracy in choosing the data according to our needs

4. Drivers of the 3 things above are the goals of the service and product targets, then after the target is determined then the right solution and application is decided

5. Data interpretation and data usability will be presented in the data presentation

6. Security Data and error handling. Data security against data privacy.

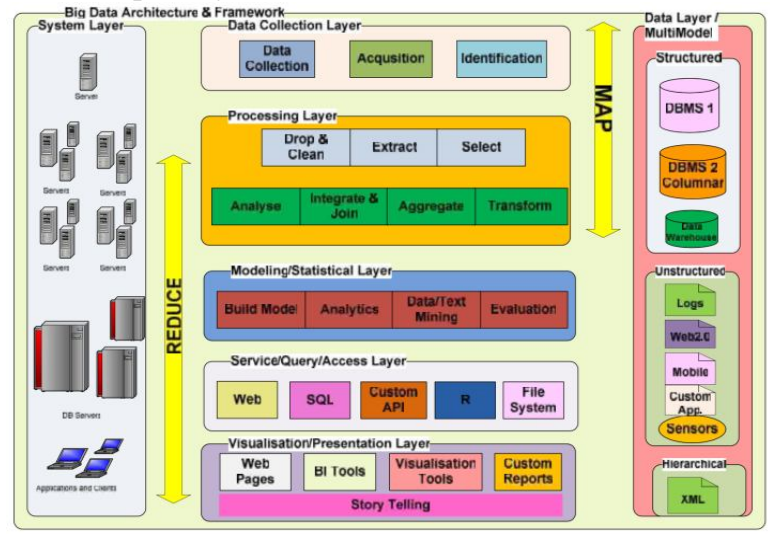

Figure 2: Big Data Framework 


\section{STEP 1}

diversity of data and sources: Select data that is appropriate and valid

The process of selecting data uses metadata from many internal and external sources that Korea has for the business. The data is united and mapped to obtain appropriate and useful data.

\section{STEP 2}

Conduct Analysis and Perform Data Modeling: this step is the next step after the data has been collected, the data must be analyzed, modeled to get the relationship between the data and identify data patterns. Must be competent in data commutation and analysis

\section{STEP 3}

Data Management and Presentation, After the data pattern is found, the data can be interpreted data on the target market

\section{FRAMEWORK SYSYEM IMPLEMENTATION DESIGN}

AND

\subsection{Design Framework}

In the Framework System and Implementation Design of Growth Hacking, there are 3 things that must be understood and prepared by the Growth Hacking Team, illustrated in the Growth Hacking element as follows Figure 3:

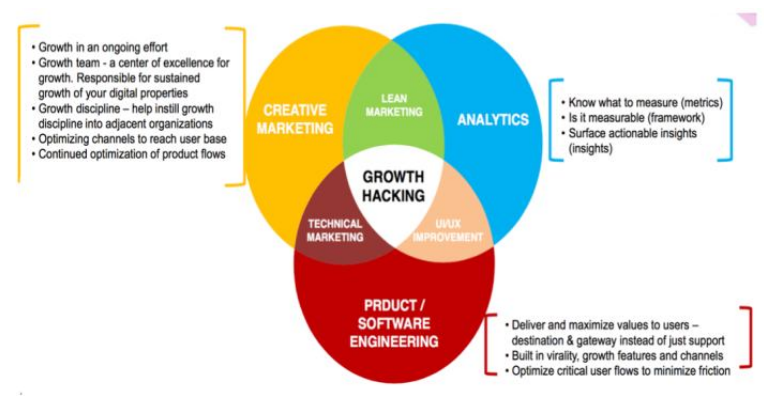

Figure 3 : Growth Hacking Element

Slices of the 3 elements above, can be explained as follows:

i. Creative Marketing is the right message delivers in the right way in order to make the sales activation. In other perspective, creative marketing is is related to marketing that puts forward the aspects of creativity and the message and design of marketing.Creative is talking about creativity in promoting digital promotion designs both traditional promotions such as leaflets, banners and others

ii. Analytic is the process of processing data, researching, looking for data patterns and connecting between one data with other data that is not known through primary data. We have to analyze data to know, to measure (metrics), to get measurable (framework), and to get surface actionable insights. This is where the role of big data is very important is needed, in order to get data that is relevant to the distribution of promotional and advertising content that matches the interest in target growth hacking

iii. Product / Software Engineering is the technical skill and a growth hacker thinking to built in virality promotion, and spread unique message related with customer behaviour

\subsection{Growth Hacking Funnel \& Design Implementation}

In the concept of growth hacking, there are standard metrics used, namely AAARRR (Awareness, Acquisition, Activation, Retention, Referral, Revenue). Growth hacking is a customer lifecycle framework. The focus of Growth Hacking is in the stage of Awareness and Acquisition. These standard metrics are often referred to as Growth Hacking Funnel.

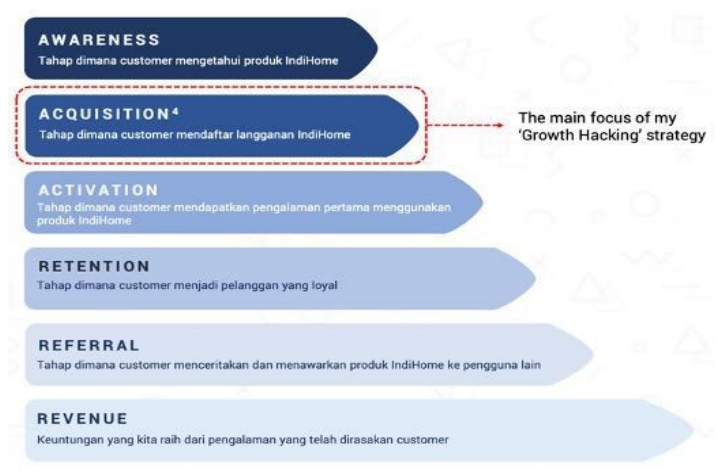

Figure 4 : Growth Hacking Funnel

After we know the stage that will be influenced a lot is the stage of awareness and acquisition, there are 2 main goals of Growth Hacking in Broadband business, that is the quantity of people who read advertising that is managed by Growth Hacking and sales obtained from mass campaigns through Growth Hacking.

\section{Growth Hacking Steps}

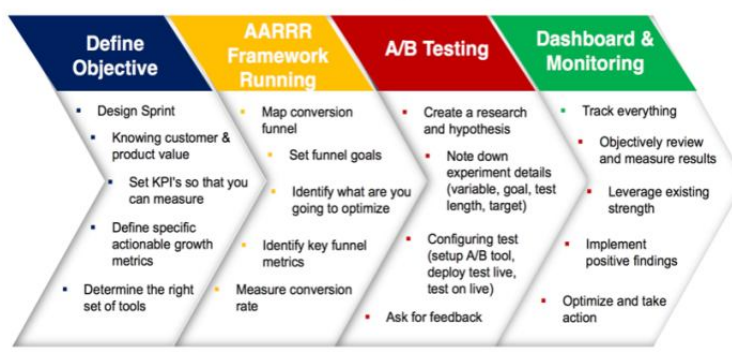

Figure 5: Growth Hacking Steps

i. Define Objective

a. Initiation of Growth Hacking Implementation for PT Telkom in 17 locations in Jakarta

b. Observation object on Growth Hacking responses related to Customer Behavior in purchasing PT Telkom products is Impression, Reach, Link Click and CTR 
i. Impressions - the meaning is the number of times the adsare displayed on the target market's page. This does not mean that the adsare seen by the target market but that the adsare already on the page and has the potential to be seen. Impression target is $100 \%$

ii. Reach - This is the number of affordable ad targets. unique nature because it is counted only once in the same person. Unlike impressions that count all ad views even if received by the same person more than once. Reach target $20 \%$

iii. Link Clicks - The number of people or target markets that clicked on ads on his social media.. Clicks target $5 \%$ from reach

iv. CTR (Click-through rate) - is the ratio of the number of people who click on an ad compared to the number of ad impressions. This figure is expressed as a percentage. $\mathrm{CTR}=($ clicks $/$ impressions $)$ * 100\%Observation about customer behaviour : comparing push channels with pull channels in the same period growth hacking implementation

c. Observation Time Implementation Growth Hacking : August - October 2018

ii. Determine AAARR ((Awareness, Acquisition, Activation, Retention, Referral, Revenue).

a. Spreading Targets Ads :

- Location based on low Occupancy Infrastructure

- Stage 1 is in 17 locations on August September 2018

- Stage 2 is in 44 regions on October 2018 in Jakarta.

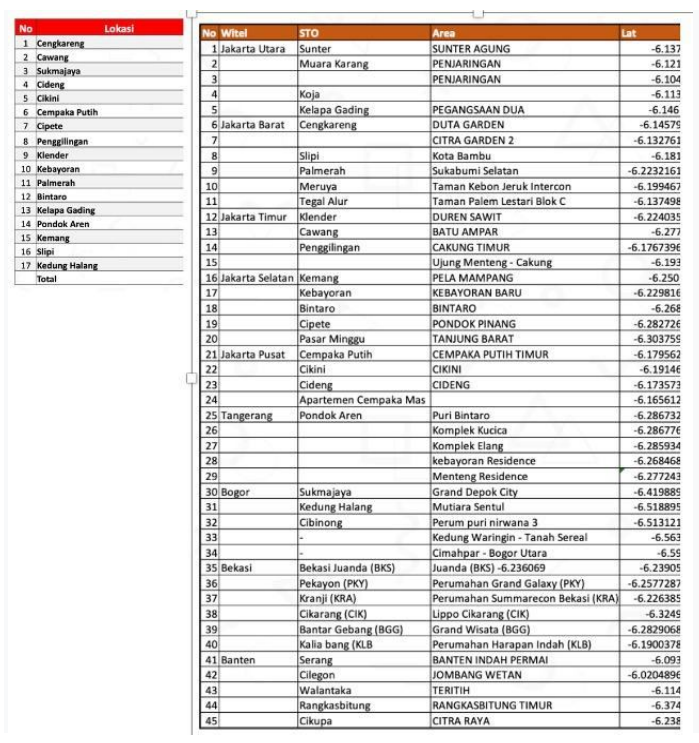

Figure 6: Area of Growth Implementation b. The high level of customer awareness of promotions in Growth Hacking is determined by the amount of reach

c. Acquisition is a way to bring in users. Usually growth hackers use certain tools available on the internet so that their products can be published for free so that many users access them. This method is often referred to as Search Engine Optimization (SEO).

d. Activation is a way for users to do something for activation on a developed site. For example after the user registers and then using the application, that can be called as activation.

e. Retention is a way for users to return to the site

f. Referral is how users invite their circle to be user. Examples of the application of referrals are people recommending your business to friends, relatives and others.

g. Revenue, namely users interested in subscribing and how to get users (sales) and make money for the company.

iii. Do A / B Testing

A/B Testing : a method used to compare two types of display applications, it can be Web, Android PlayStore, Apple Store, or other applications so that it can be used to determine which type is superior

iv. Choose and Prepare Growth Hacking Tools: To facilitate the measurement of Growth Hacking, activities tools are needed so that we are able to assess our performance :

a. Website including website analysis. By analyzing the website, we can find out the behavior of our website visitors, as well as knowing what they like, what they need, and what articles or content get many views.

b. Funnel Monitoring, third party techniques to find out in detail, the most widely known is kismetrics

c. User Survey, here used surveymonkey

d. Landing Page and A / B Testing, this can use a variety methods for visual checks, bounce rates and so on

\subsection{Big Data Analysis to determinan customer behaviour}

Various data sources are taken for customer behavior analysis. This is important because Growt hacking will spread information, promotions and advertorials directly on the target market's social media wall. If it is not appropriate, it will only be considered disturbing rubbish information

There are 2 data sources from big data processing in the implementation of growth hacking: Internal Source and Social Media Source 
From Internal Source, which is Customer Behavior based on Base Transceiver Station(BTS) and Optical Distribution Point (ODP) Broadband internet access, the data mapping will be obtained as below

The internal data mapping is called the 360 degree Customer Profiling consisting of 8 segments: location, lifestyle, mobility, active time, handset type, gender, spending money for telecommunication, and age [17].

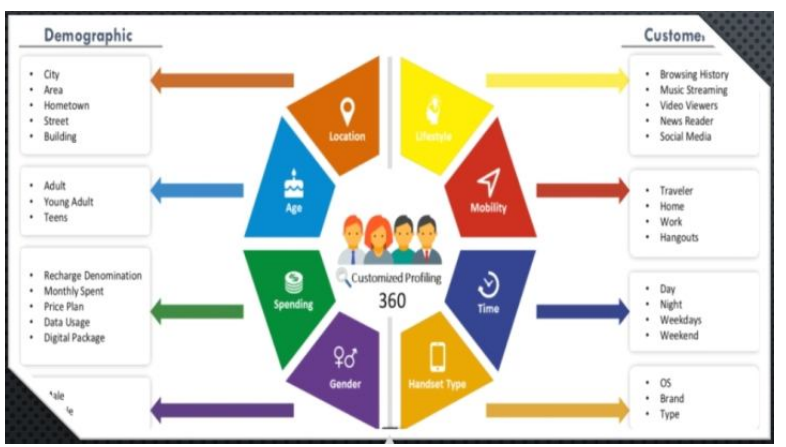

Figure 7 : 360 degree Customer Profiling

External data is obtained from several sources, mainly utilizing data that has been legally provided by Google or other data sources with certain business schemes.

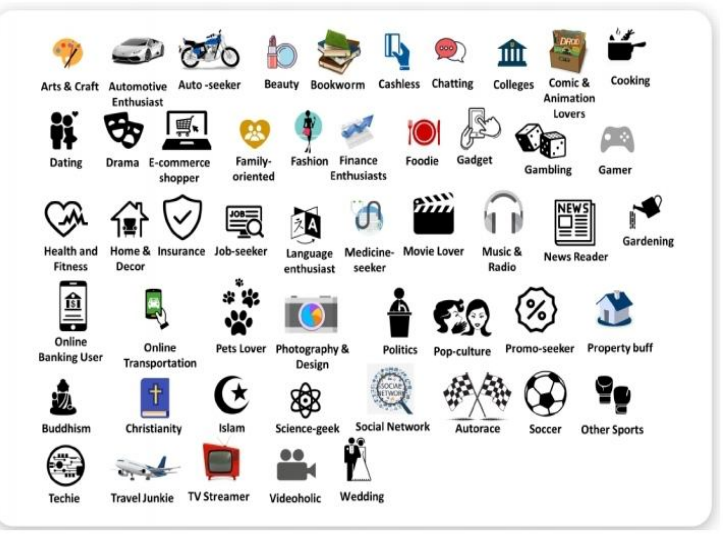

Figure 8: 51 Predefine Data Segment

With the data approach, the theme of each growth hacking activity in each locations is made based analytical data. Step by step, using big data to determine the theme is as follows:

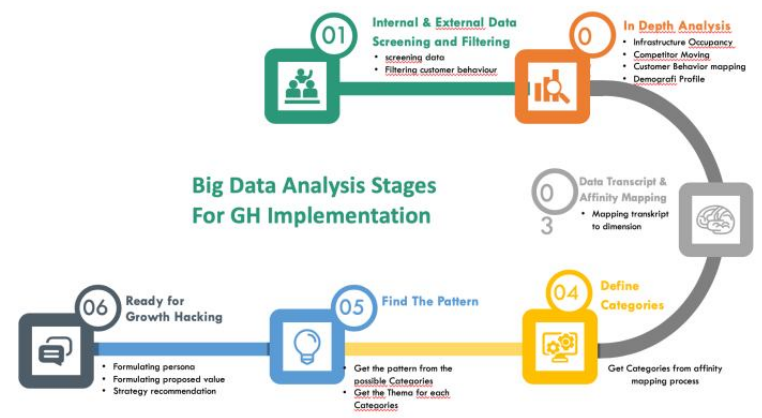

Figure 9: Big data implementation stages for determining the theme of content growth hacking

\subsection{Create Content \& Spreading in Social Media}

Based of Big Data Analytic, we could determine about content preference and the most favourite social media.

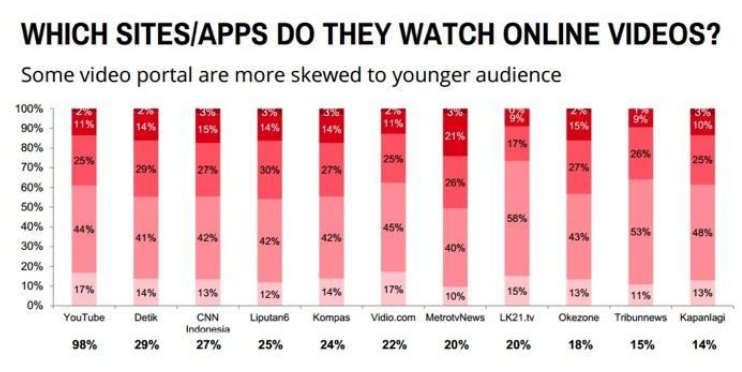

Figure 10: Preference about Favourite Site/Apps based on Internet User Age.

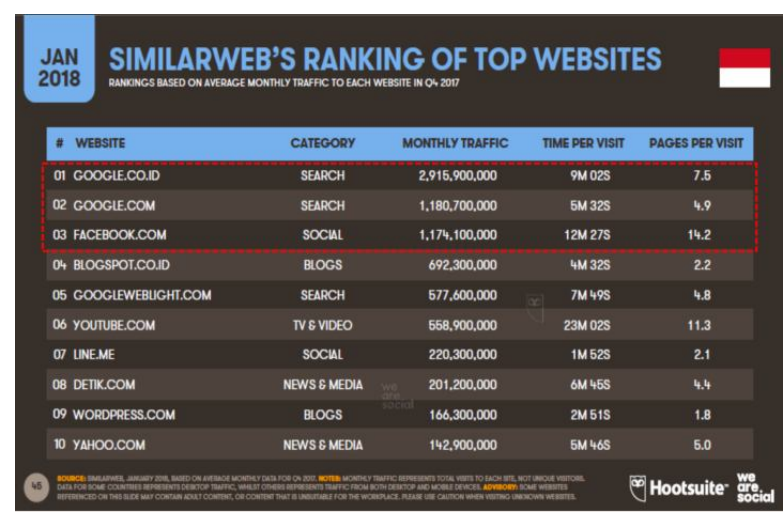

Figure 11 : Top 10 Web Site In Indonesia.

Google \& Facebook still on the big 3 of Top Website In Indonesia : Google Monthly Traffic is higher than Faceboock but let's talk about the Time per Visit, Facebook get longer time visit than Google

We Choose 4 digital media to Spread Ads about the important thing and value will be gained by the customer if they bought Broadband Internet.

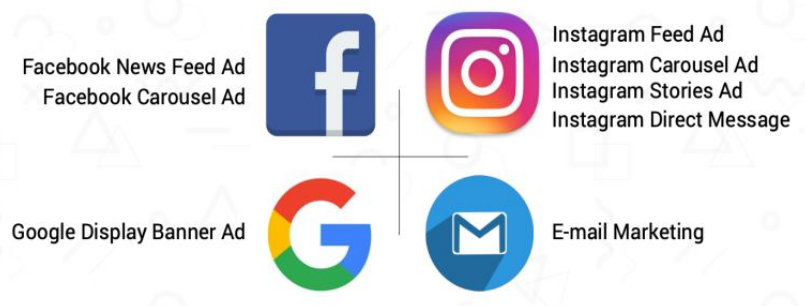

Figure 12: Social Media sites. 


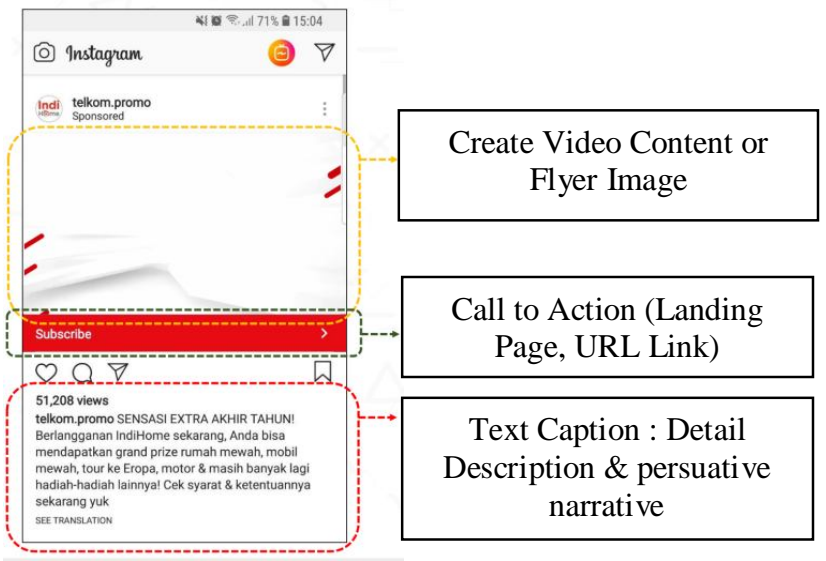

Figure 13 : Content Design

Create content design to get people awareness and get customer's willingness to click the advertising content.

Based On Big Data Analysis we know in 17 locations the people are interested with Korean Content, so we try to create Korean Content, and spread it at 17 locations.
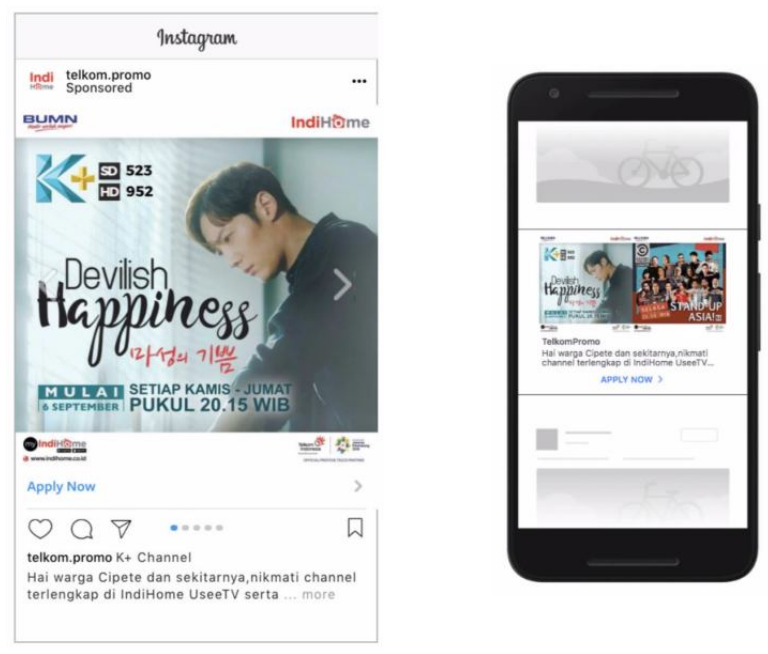

Figure 14: Sample of preferenced customer design (KPoP \& Box Office Lover)

And in other location we spread only regular content, about the value of Broadband Internet.
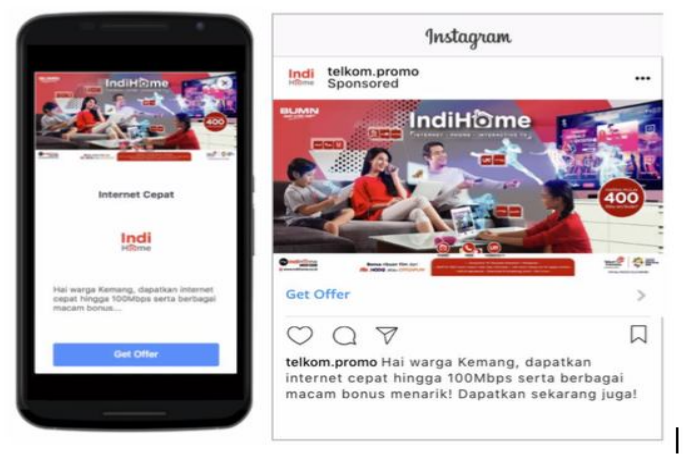

Figure 15 : Sample Design Reguler Product Offering
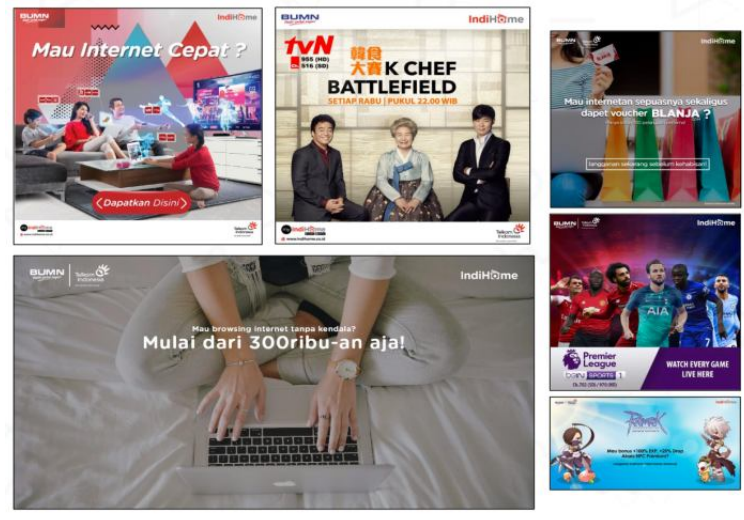

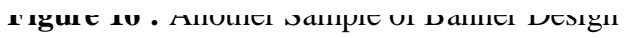

\subsection{Result and Analyze Growth Hacking Implementation}

1. Stage 1 Implementation Result

i. Facebook Ads

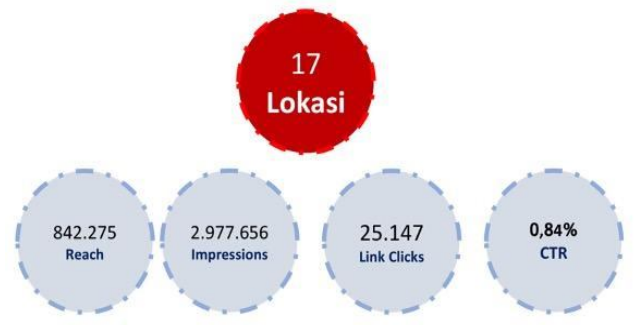

Figure 17 : Result Facebook Ads

$\begin{array}{ll}\text { Impressions } & : 2.98 \text { million } \\ \text { Reach } & : 841.000 \\ \text { Click (result) } & : 25 \mathrm{~K} \\ \text { CTR } & : 0.84 \%\end{array}$

ii. Google Ads

\begin{tabular}{|c|c|c|c|c|c|c|c|}
\hline & Campaign status & Campaign & Budget type & Campaign Trve & clicks & Imprs. & CTR \\
\hline & Enabled & Growth__Hack_IndiHome_Cawang & Dally & Display & & $0-$ & \\
\hline & & Growth_Hack_IndiHome__Slipi & Daly & Display & 5.607 & & $1,18 \%$ \\
\hline & Enabled & Growth_Hack_Inditiome_Kemar & Daly & Dissplay & 5.906 & 482.611 & $1,22 \%$ \\
\hline & $\begin{array}{l}\text { Enabled } \\
\text { Engblet }\end{array}$ & Growth_Hack_IndiHome_KelapaGading & Daly & Display & 3.598 & 2740.035 & $1,31 \%$ \\
\hline & $\begin{array}{l}\text { Ennabled } \\
\text { Enabled }\end{array}$ & 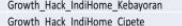 & $\begin{array}{l}\text { Daily } \\
\text { Dally }\end{array}$ & $\begin{array}{l}\text { Dispslay } \\
\text { Displat. }\end{array}$ & 5.329 & 499.960 & \\
\hline & & 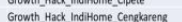 & & Display & & & $1,36 \%$ \\
\hline & Enabled & Growth_Hack_InditHome_Pond & Dally & Display & 3950 & 286.809 & 1,389 \\
\hline & & Growth_Hack_IndiHome_Pengeglingan & Dally & Display & 0 & & \\
\hline & Enabled & Growth__Hack_IndiHome_Palmerah & Dally & Display & 0 & 0- & \\
\hline & & Growth_Hack_IndiHome_CempakaPutith & Daly & Display & & 0- & \\
\hline & & Growth_HackIndithome_Bin & & Disolay & .7.749 & & 1,19\%, \\
\hline & Enabled & 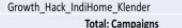 & Daliy & Dissplay & 536 & 182 & $1.25 \%$ \\
\hline
\end{tabular}

Figure 18 : Result Google Ads

$\begin{array}{lll}\text { Impressions } & : & 2.52 \text { million } \\ \text { Click (result) } & : & 31.5 \mathrm{~K} \\ \text { CTR } & : & 1.25 \%\end{array}$


2. Stage 2 Implementation Result

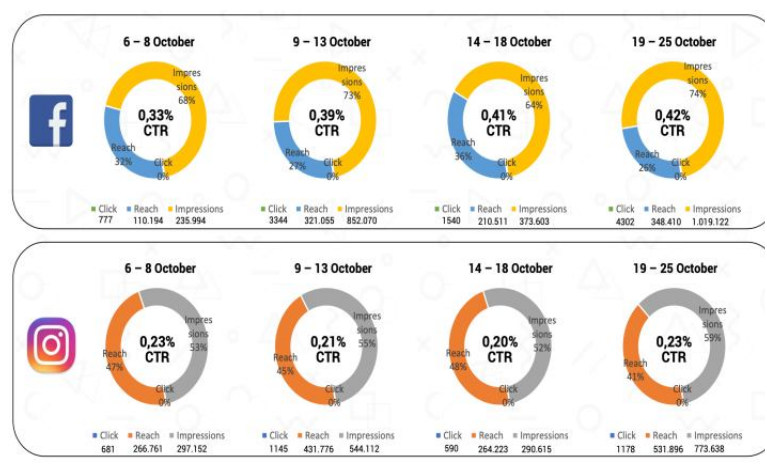

Figure 19: Result Facebook and Google Ads

\section{Result Analysis}

Compare with sales contribution before and after implementation

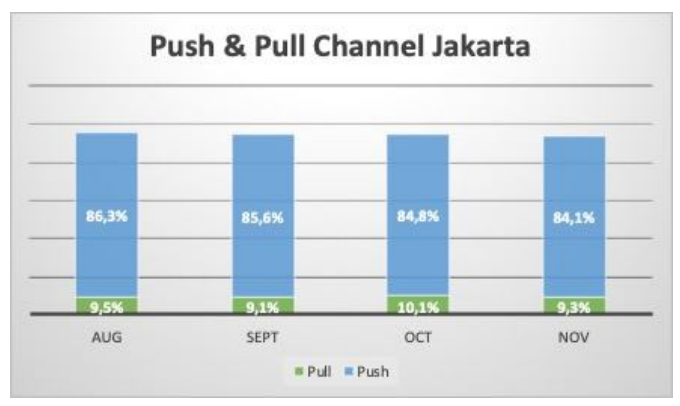

Figure 20: Push and Pull Channel Performance.

Deeply we try to compare the Mapping of Push \& Pull Channel in the same period on Jakarta. Pull dan Push Channel Chart in Jakarta From August to November shows that Pull Channel slightly increase $\mathbf{0 . 2 \%} \mathbf{- 0 . 4 \%}$ on September \& October 2018. It can be assumed as Growth Hacking sales,

\begin{tabular}{|c|c|c|c|c|c|c|c|c|c|c|c|c|}
\hline Witel & Berminat Cancel & konfirmasi & $\begin{array}{l}\text { Proses } \\
\text { follow Up }\end{array}$ & $\begin{array}{c}\text { Tidak } \\
\text { perminat }\end{array}$ & $\begin{array}{c}\text { Sudah } \\
\text { It Berlangzanan }\end{array}$ & Total Reg & Reg HI & Input & & Kendala & $\begin{array}{c}\text { Proses } \\
\text { Call }\end{array}$ & \\
\hline Banten & 2 & & 1 & 3 & & 6 & & 0 & 0 & 1 & 1 & 0 \\
\hline Bekasi & & & 1 & & 1 & 4 & & 0 & 0 & & & \\
\hline Bogor & 2 & & & 5 & & 11 & & 1 & 1 & 0 & & \\
\hline Tangerang & 2 & & 3 & & 1 & 20 & & 1 & 0 & 1 & 1 & \\
\hline Jakarta Selatan & 7 & & 27 & & 10 & 52 & & 5 & 3 & 0 & 0 & 4 \\
\hline Jakarta Barat & 12 & & 35 & & 12 & 72 & & 9 & 3 & 2 & 2 & \\
\hline ita Tir & 2 & 1 & 10 & & 3 & 21 & & 1 & 11 & 0 & 0 & 3 \\
\hline Jakarta Utara & 1 & & 1 & 6 & 8 & 18 & & 1 & 11 & 0 & & 2 \\
\hline Jakarta Pusat & $4^{4}$ & & 1 & 6 & & 14 & & 3 & 33 & 0 & & 3 \\
\hline Total & 32 & 1 & 103 & 03 & 35 & 218 & 4 & $4 \quad 21$ & 112 & 4 & 4 & 29 \\
\hline
\end{tabular}

Figure 21 : Sales Performance From Growth Hacking

if we take sales contribution from Growth Hacking currently on September and October 2018, we can see that the contribution very small.

Sales order From Growth Hacking after customer click ads it reaches only 218 orders, or if compare with Sales On Jakarta Area with average 35.000 per month or 70.000 on two month , so only $218 / 70.000=0.3 \%$ (sales contribution from growth hacking)

\section{Potential Registration by Growth Hacking}

a. It's Amazing if talk about the reach of ads in 2 month, we can promote to 841.000 Facebook users in area that we had choosen

b. How many people and how much time we will need if we use push channel methods (door to door or open table)? The results shows that it's very potential if you need smart and fast method to spread information about product.

c. Talk about link clicks: we had 25.147 people in two month by Facebook and 31.536 people by Google. I Think it considered small compared with impression we have in $0.84 \%$ by Facebook and $1.25 \%$ by Google.

Compare Implementation Growth Hacking with Theory: The level of success of creative marketing determines the success of Growth Hacking. If we compare Impression, Click and Registration, we will know that level of success of The Implementation of Growth Hacking in Jakarta is very small on level "Search". CTR (click through rate) Facebook : 0,84 $\%$, Google Ads : 1,25\%.

\section{CONCLUSION AND FUTURE WORK}

we have some conclusion about growth hacking implementation in Jakarta:

a. With Big Data the spread of promotions and advertising can be in accordance with customer behavior, in this case for Growth Hacking can identify content distribution through Korean content in locations that are AIDAdestination

b. Based on implementation in growth hacking, Fig.9 shows there are 6 steps that can be used to determine the appropriate schedule to deliver the content.

c. We can spread information with smart design dan quickly, but contribution from Sales From Growth Hacking smaller than traditional channel (Sales Force). The increase of sales from Growth Hacking between $0.2 \%-0,4 \%$

d. With very big Impression \& reach, it can be potential to spread information about product and service to potential customer in specific area

e. There has not been any change in customer behavior from push approach by traditional channel (sales force and point of sales) to Digital approach (growth hacking in this case

f. Deeply need research to know about customer behavior related with Growth Hacking Implementation: (1) Why Customer don't clicks after we receive some advertising/promotion, (2) Internet penetration and social media user is very big, but why aren't there any new approach to offer product with growth hacking, (3) Is there a relationship between age, social media application and products/service offering? (4) Related to the integrated marketing concept, is there any relationship between implementation only? Growth Hacking or we have to combine with other marketing communication approaches? (5) Is there 
influence on prices, products, communication design in growth hacking ads with the desire to click and fulfill the registration form?

\section{REFERENCES}

[1] Al-Fuqaha, A., Guizani, M., Mohammadi, M., Aledhari, M., \& Ayyash, M. (2015). Internet of Things: A survey on enabling technologies, protocols, and applications. IEEE Communications Surveys \& Tutorials, 17(4), 2347-2376.

[2] Atzori, L., Iera, A., \& Morabito, G. (2010). The Internet of Things: A survey. Computer Networks, 54(15), 2787-2805.

[3] Borgia, E. (2014). The Internet of Things vision: Key features, applications and open issues. Computer Communications, (54), 1-31

[4] Bussgang, J. and Benbarak, N. (2016) Every company needs a growth manager. Available at: https://hbr.org/2016/02/every-company-needs-agrowth-manager (Accessed: 29 April 2016).

[5] Chae, B. K. (2019). The evolution of the Internet of Things (IoT): A computational text analysis. Telecommunications Policy, 43(10), 101848

[6] Chae, B. K. (2015a). Big data and it-enabled services: Ecosystem and coevolution. IT Professional, 17(2), 20-25.

[7] Elezovic, V. (2017). The value of Growth Hacking. Business development manual for Emi-Rent Properties.

[8] Ho, S. Y. (2016). Making Sense of Growth Hacker Marketing.

[9] Knieps, G. (2019). Internet of Things, big data and the economics of networked vehicles. Telecommunications Policy, 43(2), 171-181.

[10] Miotk, A. (2018). Growth Hacking-Low Cost Marketing Communication for Small Businesses. Marketing i Rynek, (12), 23-35.
[11] Pudełek, M., Pieczyński, S. (2017). Growth Hacking czarnym koniem marketingu? Poznaj trzy mity o hakowaniu wzrostu. Pozyskano z/ Retrieved from: https://nowymarketing.pl/a/12915, growth-hackingczarnym-koniem-marketingu-poznaj-trzy-mity-ohakowaniu-wzrostu..

[12] Oancea, O. E. M. (2015). The Model of Integrated Marketing Communication: Who has the Role to Influence Consumer Behaviour. Acta Universitatis Danubius. Economica, 11(1), 22-31

[13] Sineni, S. L. (2014). Growth Hacking: A Deep Look into Online Marketing for Startups (Doctoral dissertation, University of Southern California).

[14] Tekiner, F., \& Keane, J. A. (2013, October). Big data framework. In 2013 IEEE International Conference on Systems, Man, and Cybernetics (pp. 1494-1499). IEEE.

[15] A. Hausman (2017, July). Growth Hacking: Using Big Data to Generate Bankable Results Retrieved from: www.hausmanmarketingletter.com/growth-hackingbig-data-big-opportunity/

[16] SAS Insights. Big Data: What it is and why it matters:

Retrieved from:

https://www.sas.com/en_id/insights/big-data/what-isbig-data.html.

[[17]. Pertiwi,A.P., Puri D., Pratama, Y.A.,Sfenrianto, Wang, G. (2020). Analysis Loyalty in Video Conference Application room on Covid19 quarantine in Jakarta. International Journal of Advanced Trends in Computer Science and Engineering, 9(3),pp.2724-2728. 